\title{
ANALISA TRIWULANAN: \\ Perkembangan Moneter, Perbankan dan Sistem Pembayaran, Triwulan III - 2005
}

\author{
Tim Penulis Laporan Triwulanan, Bank Indonesia
}

Perekonomian Indonesia dalam triwulan III -2005 menunjukkan kinerja yang tidak sebaik perkiraan semula, dengan pertumbuhan ekonomi yang diperkirakan lebih rendah sementara tekanan terhadap stabilitas makroekonomi meningkat. Tingginya harga minyak dunia dan ekspansi ekonomi domestik yang bertumpu pada impor telah menimbulkan tekanan yang besar terhadap kondisi neraca pembayaran dan pengeluaran subsidi BBM Pemerintah. Dari sisi moneter, kondisi tersebut telah menyebabkan tekanan terhadap pelemahan nilai tukar rupiah dengan volatilitas yang meningkat, sementara inflasi masih relatif tinggi terutama karena dampak kenaikan administered price, volatile foods, dan meningkatnya ekspektasi inflasi. Ke depan, tekanan pada inflasi diperkirakan masih akan besar terutama sebagai dampak kenaikan harga BBM pada tanggal 1 Oktober 2005. Bank Indonesia memandang bahwa meningkatnya ekspektasi inflasi dan depresiasi nilai tukar rupiah tersebut dapat meningkatkan risiko ketidakstabilan markoekonomi yang dapat mengganggu keberlangsungan pertumbuhan ekonomi dalam jangka panjang. Sehubungan dengan itu, Bank Indonesia terus menempuh langkah-langah stabilisasi moneter dengan menaikkan suku bunga BI Rate secara signifikan yang dibarengi dengan upaya peningkatan pengelolaan likuiditas secara optimal, disamping langkah-langkah kebijakan yang secara langsung ditunjukan untuk stabilisasi nilai tukar rupiah. Berbagai langkah tersebut merupakan respon kebijakan Bank Indonesia untuk secara konsisten mengarahkan ekspektasi inflasi agar sesuai dengan pencapaian sasaran inflasi jangka menengah.

Pertumbuhan ekonomi pada triwulan II-2005 lebih rendah dari perkiraan. PDB diperkirakan tumbuh sebesar 5,2 \%-5,7\% (y-o-y), atau mengalami revisi ke bawah dari perkiraan pada triwulan sebelumnya sebesar 5,5-6,0\%. Perlambatan pertumbuhan ini berkaitan dengan berbagai kendala di sisi produksi dalam memenuhi permintaan domestik yang tumbuh masih cukup kuat. Lemahnya respon sisi penawaran tersebut akibat dari lambannya kebijakan struktural dan parbaikan investasi, menurunnya persepsi bisnis, serta meningkatnya biaya produksi yang terkait dengan kenaikan harga administered dan pelemahan nilai tukar. Sementara itu, 


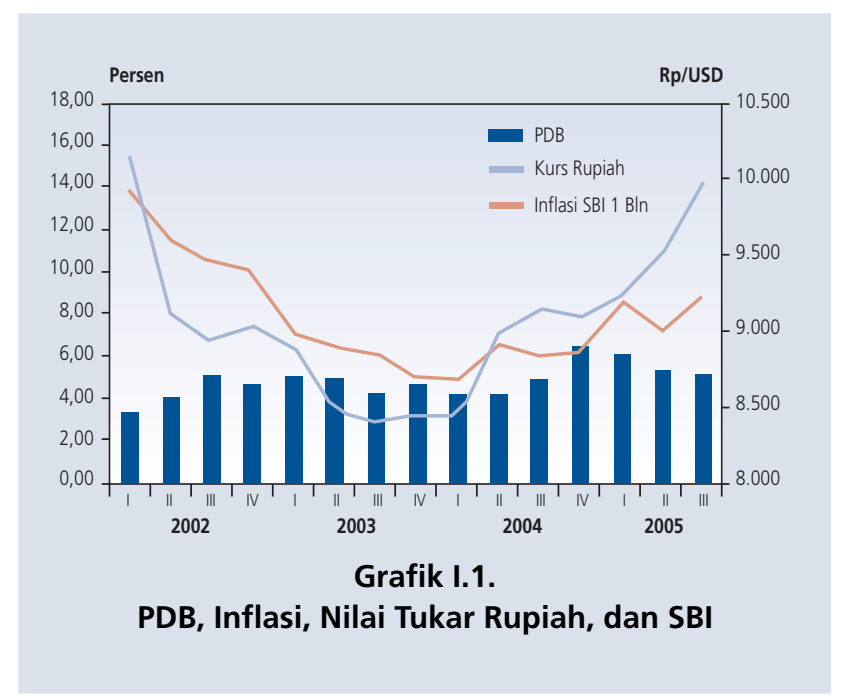

permintaan domestik tetap tumbuh relatif tinggi meskipun menunjukkan kecenderungan menurun sebagaimana ditunjukkan oleh sejumlah indikator penuntun (leading indicators). Kegiatan investasi diprakirakan tetap tumbuh relatif cukup tinggi yaitu sekitar 15\%. Pertumbuhan konsumsi diprediksikan menurun meskipun dalam bebrapa bulan terakhir mulai menunjukkan tanda-tanda meningkat terutama yang berasal dari pengeluaran Pemerintah. Peningkatan permintaan domestik yang tidak diimbangi oleh penambahan kapasitas perekonomian ini menyebabkan tingkat kesenjangan output perekonomian nasional semakin menyempit.

Permintaan domestik yang masih tumbuh cukup tinggi telah menimbulkan tekanan pada neraca pembayaran. Peningkatan kegiatan ekonomi telah mendorong peningkatan impor, khususnya impor bahan baku dan barang modal. Sementara itu, kinerja ekspor yang diharapkan dapat memperoleh keuntungan dari lonjakan harga minyak dan peningkatan harga sejumlah komoditi ekspor masih ternyata belum dapat mengimbangi peningkatan impor tersebut.Ekspor masih tumbuh terbatas karena rendahnya daya saing di tengah pertumbuhan ekonomi global yang melambat, serta kegiatannya yang terlalu mengandalkan komiditas berbasis sumber daya alam dan hasil pertanian. Perkembangan ini menyebabkan, kinerja neraca transaksi berjalan yang masih mencatat surplus pada triwulan I-2005 telah mengalami defisit sejak triwulan II2005. Sementara itu, kinerja neraca modal juga belum menunjukkan perbaikan dengan aliran dana keluar untuk pembayaran utang dan impor yang semakin meningkat sementara aliran dana masuk masih terbatas. Dengan perkembangan tersebut, secara keseluruhan neraca pembayaran mengalami defisit sebesar USD 2,3 miliar pada triwulan III-2005, atau lebih besar dibandingkan perkiraan sebelumnya sebesar USD 1,1 miliar. 
Menurunnya kinerja neraca pembayaran telah memberikan tekanan secara fundamental terhadap nilai tukar rupiah. Kurs rupiah mengalami pelemahan yang tajam, dari rata-rata Rp. 9.556 per USD selama triwulan II-2005 menjadi Rp. 10.013 per USD selama triwulan III-2005 atau terdepresiasi $4,8 \%$. Pelemahan nilai tukar rupiah juga diiringi dengan meningkatnya volatilitas dari 1,38\% menjadi 2,72\% pada triwulan III-2005. Dari sisi internal, pelemahan nilai tukar rupiah terkait dengan besarnya permintaan valas baik untuk kebutuhan impor maupun pembayaran utang luar negeri sedangkan pasokan valas relatif terbatas. Dari sisi eksternal, meningkatnya tekanan depresiasi nilai tukar rupiah terkait dengan meningkatnya suku bunga di pasar internasional, lonjakan harga minyak dunia, serta penguatan dolar sejalan dengan masih berlanjutnya siklus pengetatan moneter di AS. Tekanan terhadap rupiah diperburuk dengan sentimen negatif dari persepsi pasar atas kondisi sustainabilitas fiskal Pemerintah dalam menanggung besarnya BBM akibat tingginya harga minyak. Dalam kondisi perbankan yang masih mengalami ekses likuiditas, meningkatnya permintaan valas pada gilirannya memicu sejumlah perusahaan domestik dan nasabah individu untuk ikut membeli valas (bandwagon effect) di pasar sehingga tekanan pada nilai tukar rupiah semakin besar.

Inflasi IHK meningkat tajam hingga mencapai 9,06\% (y-o-y). Peningkatan tersebut berasal dari kenaikan inflasi kelompok barang makanan tertentu yang harganya berfluktuasi (volatile foods), masih tingginya kenaikan administered prices, serta peningkatan ekspektasi inflasi sehubungan dengan rencana pemerintah untuk kembali menaikkan harga BBM pada awal Oktober 2005 dan melemahnya nilai tukar rupiah. Peningkatan ekspektasi ini tercermin dari hasil survei konsumen dan survei pedagang eceran yang menunjukkan bahwa ekspektasi inflasi masyarakat semakin meningkat. Volatile foods dan administered akhir triwulan III-2005 mencatat level yang tinggi masing-masing 12,46\% dan 12,65\% (y-o-y). Laju inflasi IHK semakin tinggi dengan terhambatnya distribusi sejumlah kebutuhan pokok di beberapa daerah dan penyesuaian harga kelompok administered seperti kanaikan harga pokok, tarif tol dan tarif PAM. Sementara itu, meskipun mengalami sedikit penurunan inflasi inti relatif stabil di sekitar 6,73\%. Masih tingginya inflasi masyarakat serta pengaruh pelemahan kurs rupiah. Sementara itu, tekanan inflasi yang berasal dari sisi kesenjangan output relatif kecil. Secara keseluruhan, inflasi IHK masih lebih tinggi dari sasaran inflasi yang ditetapkan oleh Pemerintah untuk tahun 2005 sebesar $6 \%+/-1 \%$.

Dalam rangka mengendalikan laju inflasi sesuai dengan sasaran inflasi jangka menengah, kebijakan moneter yang cenderung ketat (tight bias) terus dilanjutkan. Kebijakan ini tercermin pada kenaikan BI Rate secara bertahap sehingga mencapai 10\% pada akhir triwulan III-2005. Selain itu, Bank Indonesia juga melakukan penyerapan kelebihan likuiditas rupiah melalui instrumen Operasi Pasar Terbuka (OPT) dan sejumlah langkah seperti mengaktifkan kembali 
instrumen Fine Tune Kontraksi (FTK) dengan variable rate tender, menaikkan GWM berdasarkan tingkat LDR, dan menaikkan imbalan jasa giro dari semula 3\% menjadi 5,5\% untuk seluruh tambahan GWM rupiah di atas 5\%. Bank Indonesia juga menaikkan suku bunga FASBI 7 hari sebesar $100 \mathrm{bps}$ menjadi $8,5 \%$ dan suku bunga penjaminan baik rupiah maupun valas. Di bidang valas, Bank Indonesia menerapkan paket kebijakan yang pada prinsipnya mencakup pengelolaan permintaan valas, meminimalkan ekses likuiditas di sektor perbankan, membatasi transaksi valas yang tidak disertai kegiatan ekonomi, menyediakan fasilitas swap untuk kepentingan investor, memberlakukan intervensi swap valas sebagai instrumen OPT dan menyempurnakan ketentuan Posisi Devisa Neto.

Kenaikan BI Rate direspon oleh suku bunga perbankan dan perubahan harga aset khususnya pasar saham reksa dana. Di sektor perbankan, kenaikan BI rate diikuti peningkatan suku bunga simpanan, namun belum tertransmisikan ke suku bunga kredit, sehingga kenaikan $\mathrm{BI}$ rate belum mempengaruhi volume kredit perbankan. Secara umum, kondisi intermediasi perbankan masih cukup baik, tercermin dari tingkat Loan to Deposit Ratio (LDR) yang mencapai $54,5 \%$. Sementara itu, di pasar saham, obligasi, dan reksadana, kenaikan suku Bunga BI Rate juga berpengaruh pada perilaku pemain, yang juga diwarnai sentimen negatif berkaitan dengan tingginya harga minyak, prospek kesinambungan fiskal, dan rencana kenaikan BBM. Kondisi pasar saham ditandai dengan penurunan harga saham yang cukup besar sehingga menekan indeks harga saham gabungan (ISHG) dari 1.136 menjadi 1.044. Di pasar obligasi, harga Surat Utang Negara (SUN) juga mengalami penurunan hingga di bawah harga par-nya. Demikian pula di pasar reksa dana, Nilai Aktiva Bersih (NAB) reksa dana merosot lebih dari 50\%, menjadi Rp. 32,7 triliun. Kondisi pasar saham dan reksa dana yang kurang bergairah (bearish) tersebut, menyebabkan perusahaan yang mengupayakan pembiayaan kegiatan usaha melalui pasarpasar tersebut mengalami penurunan.

Ke depan, untuk keseluruhan tahun 2005 pertumbuhan ekonomi diperkirakan akan sedikit lebih rendah dari perkiraan sebelumnya meskipun masih lebih tinggi dibandingkan dengan pertumbuhan tahun sebelumnya. Pertumbuhan ekonomi diperkirakan akan mencapai 5,7\%, atau tetap pada kisaran 5,5-6,0\%, sedikit lebih rendah dibandingkan perkiraan pada triwulan sebelumnya, 5,9\%. Revisi ke bawah ini disebabkan oleh perkiraan menurunnya kinerja investasi dan ekspor dari perkiraan semula karena adanya proses penyesuaian pelaku ekonomi dalam merespon dampak harga minyak, pelemahan nilai tukar, dan menuunnya prospek investasi. Secara sektoral, pertumbuhan ekonomi tersebut tetap didukung oleh sektor industri pengolahan, sektor perdagangan, serta sektor pengangkutan dan komunikasi. Sementara itu, kondisi neraca pembayaran diperkirakan belum membaik dan masih akan mencatat defisit sekitar USD3,8 miliar, karena masih tingginya kebutuhan impor dan pembayaran utang luar negeri sementara prestasi ekspor masih belum dapat diandalkan. 
Di bidang harga, kenaikan harga BBM akan menjadi sumber tekanan inflasi khusunya di tahun 2005. Berdasarkan kajian dampak kenaikan harga BBM terhadap inflasi menunjukkan bahwa kenaikan harga BBM rata-rata sekitar $80 \%$ akan memberikan sumbangan inflasi sekitar $3 \%$. Dengan memperhitungkan dampak langsung maupun tidak langsung dari kenaikan harga BBM yang ditetapkan Pemerintah, serta tekanan inflasi karena faktor musiman terkait dengan hari besar keagamaan, tingkat inflasi IHK dalam beberapa bulan ke depan diperkirakan meningkat cukup signifikan hingga mencapai sekitar 12\% (y-o-y) pada akhir 2005. Tekanan inflasi dapat lebih besar apabila dampak lanjutan kenaikan harga BBM terhadap biaya transportasi dan hargaharga lain tidak dapat terkendali. Perkiraan inflasi IHK tersebut sekaligus merevisi ke atas perkiraan akan stabil pada level yang cukup tinggi, yaitu 7,3\% pada akhir tahun 2005 atau pada kisaran 7\%-9\%. Tekanan inflasi inti terutama disebabkan oleh tingginya ekspektasi inflasi dan faktor melemahnya nulai tukar rupiah. Secara keseluruhan, perkiraan inflasi IHK untuk tahun 2005 akan jauh di atas sasaran inflasi yang ditetapkan Pemerintah sebesar $6 \%+/-1 \%$.

Untuk tahun 2006, kondisi perekonomian Indonesia diperkirakan akan lebih baik bila dibandingkan tahun 2005. PDB diperkirakan tumbuh sekitar 5,9\% atau pada kisaran 5,5$6,5 \%$. Perkiraan ini lebih rendah dibandingkan perkiraan PDB pada triwulan sebelumnya sebesar $6,1 \%$. Pertumbuhan PDB tersebut tetap disertai dengan pola ekspansi yang mengandalkan kegiatan investasi dan ekspor. Optimisme dunia usaha sebagaimana hasil survei SKDU dan tersedianya aspek pembiayaan diperkirakan turut mendukung tumbuhnya investasi. Sementara itu, membaiknya daya beli masyarakat seiring dengan meredanya dampak kenaikan harga administered diperkirakan akan mendorong kegiatan konsumsi swasta. Kondisi eksternal yang relatif lebih kondusif dibandingkan tahun 2005 juga diperkirakan akan mendorong peningkatan kegiatan ekspor. Akan tetapi, indikator kestabilan makroekonomi khususnya nilai tukar rupiah diperkirakan masih menghadapi tantangan. Kondisi neraca pembayaran yang semakin memburuk menyebabkan nilai tukar diperkirakan pada arah yang cenderung lemah. Sementara itu, tekanan inflasi IHK diperkirakan akan jauh lebih rendah dibandingkan tahun 2005 yaitu sekitar 6\%-8\% di tahun 2006, seiring dengan telah merendanya tekanan administered price.

Dengan mempertimbangkan perkembangan tersebut dan prospek ekonomi moneter ke depan, kebijakan moneter yang cenderung ketat tetap dilanjutkan. Bank Indonesia memandang bahwa meningkatnya ekspektasi inflasi dan depresiasi nilai tukar rupiah dapat meningkatkan risiko ketidakstabilan makroekonomi. Upaya, menjaga kestabilan makroekonomi sangat diperlukan untuk menjaga keberlangsungan pertumbuhan ekonomi dalam jangka panjang. Dalam kaitan ini, Rapat Dewan Gubernur (RDG) pada tanggal 4 Oktober 2005 telah memutuskan untuk menaikan BI Rate sebesar 100 basis poin menjadi 11,0\%. Kenaikan BI Rate ini merupakan respon kebijakan BI untuk secara konsisten mengarahkan ekspektasi inflasi agar sesuai dengan pencapaian sasaran inflasi jangka menengah dan tetap mecerminkan tingkat suku bunga riil 
yang wajar. Stance kebijakan moneter ini ditempuh dengan dibarengi upaya pengelolaan likuiditas secara lebih optimal. Untuk menjaga volatilitas nilai tukar rupiah yang berlebihan, Bank Indonesia akan tetap mengambil langkah sterilisasi valas secara terukur. Selain itu, Bank Indonesia juga akan meningkatkan koordinasi dengan Pemerintah untuk meminimalkan dampak lanjutan dari kenaikan harga BBM terhadap inflasi. Dalam kaitan ini, Bank Indonesia dari waktu ke waktu akan melakukan asesmen perkembangan dan prospek perekonomian sehingga, apabila diperlukan, melakukan penyesuaian BI rate pada RDG bulan-bulan berikutnya. 